\title{
Use of different SEM techniques in the study of Tyrophagus putrescentiae (Acari: Acaridae) in Costa Rica
}

\author{
Pamela Murillo ${ }^{1,2}$, Hugo Aguilar ${ }^{1,2}$, \& Ethel Sanchez ${ }^{2}$ \\ 1. Laboratorio de Acarología, Museo de Insectos, Centro de Investigaciones en Protección de Cultivos (CIPROC), Escuela de Agronomía, Facultad \\ de Ciencias Agroalimentarias, Universidad de Costa Rica, San José, Costa Rica; pamela.murillo@ucr.ac.cr, hugo.aguilar@ucr.ac.cr \\ 2. Centro de Investigaciones en Estructuras Microscópicas (CIEMic), Universidad de Costa Rica, San José, Costa Rica; ethel.sanchez@ucr.ac.cr
}

Received 19-III-2013 Corrected 30-IV-2013 Accepted 14-V-2013

\begin{abstract}
Scanning electron microscopy (SEM) has been used as a tool to facilitate the morphological description of mites and to complement the information obtained from the light microscope. Unfortunately, several of SEM techniques used for soft-bodied mites such as Tyrophagus, have in many cases not shown the desired results. This investigation sought to develop an efficient procedure for preparing specimens of T. putrescentiae for SEM so that its major morphological characters could be observed and photographed. This species is the most important contaminant of tissue culture laboratories in Costa Rica. Seven methods were used to process the samples. The evaluated treatments showed differences in their ability to preserve the morphological structures of the specimens. The advantages and disadvantages of each treatment are discussed. Mites processed using ethanol were the most viable option with method 3 being the procedure that showed the best results; this technique also reduced the time and costs of processing the specimens.
\end{abstract}

\section{KEY WORDS}

Acari, Acaridae, Tyrophagus putrescentiae, Scanning Electron Microscopy (SEM), SEM techniques

\section{RESUMEN}

El microscopio electrónico de barrido (MEB) ha sido utilizado como una herramienta para complementar la información obtenida bajo el microscopio de luz. Desafortunadamente, muchas de las técnicas utilizadas con el MEB para ácaros de cuerpo suave como Tyrophagus, no han mostrado los resultados deseados en muchos casos. El presente trabajo buscó un procedimiento eficiente para observar y fotografiar bajo MEB los caracteres morfológicos más importantes de T. putrescentiae. Esta especie es el principal contaminante en cultivo de tejidos vegetales en Costa Rica. Se utilizaron siete tratamientos para el procesamiento de las muestras. Los tratamientos evaluados mostraron diferencias entre sí con respecto a la preservación de las estructuras de los especímenes. Se discuten las ventajas y desventajas de cada procedimiento. Los tratamientos con etanol fueron la opción más viable para procesar estos ácaros, siendo el tratamiento 3 el que mostró mejores resultados. Asimismo, esta técnica permite reducir tanto el tiempo como los costos durante el procesamiento de los especímenes.

\section{PALABRAS CLAVE}

Acari, Acaridae, Tyrophagus putrescentiae, Microscopio Electrónico de Barrido (MEB), Técnicas MEB
The production and export of plants cultivated in vitro has reached a high level in Costa Rica. Plant tissue culture has had a great impact on the improvement of quality and quantity of commercially important cultivated crops and ornamental plants (Serageldin, 1999; Valdez, López \& Jiménez, 2004). However, microbial contamination of the plantlets cultivated in vitro has caused major losses in production, ranging from 3\% to $55 \%$ (Boxus \& Terzi, 1987; Leifert, Morris \&Waites, 1994). Viruses, bacteria, yeasts, fungi, mites, and thrips are among the major contaminants of vegetable tissues (Leifert \& Cassells, 2001).

Infestations caused by mites are difficult to manage. Once they gain entry into the laboratory, they are often able to migrate from one vessel to another, quickly spreading throughout the work area. Their population rapidly increases and they often become pests in the new, favorable environment (Aguilar, Murillo \& Gómez, 2006; Duek, Kaufman, Palevsky \& Berdicevsky, 2001). To properly control mites as contaminants of tissue culture, it is essential 
to identify which species are involved, since many of the strategies for controlling are very specific.

The mold mite, Tyrophagus putrescentiae (Schrank) is the major mite species found on plants cultivated under in vitro conditions in the laboratories in Costa Rica. The females usually range in size from 320 to $420 \mu \mathrm{m}$ and males from 280 to $350 \mu \mathrm{m}$ in length (Blake, 1988; Leifert et al., 1994; Zhang, 2003). They possess various morphological important characteristics, which due to their reduced size, are difficult to observe. Thus, for example, to discriminate among the species, characteristics such as the dentition on the chelicerae, the dorsal setae, supracoxal seta, leg chaetotaxy, pretarsus claws, genital organs, setae on the anal aperture, solenidia, and spines, among other characteristics of the genus, are taken into account (Hughes, 1976; Zhang, 2003; Fan \& Zhang, 2007; Klimov \& OConnor, 2009).

Different SEM techniques have been used for the observation and analysis of surface structures, providing important information about the relief, texture, size and shape, both on biological and mineral samples (Postek, Howard, Johnson \& McMichael, 1980). The electron microscope has been used during the last 30 years, as a tool to facilitate morphological descriptions of mites and as a complement of information obtained under the light microscope (Keirans, Clifford \& Corwin, 1976; Wergin, Ochoa, Erbe, Craemer \& Raina, 2000; Achor et al., 2001; Ochoa, Erbe, Wergin, Frye \& Lydon, 2001; Mariana, Santana, Ho, Tan \& Zuhaizam, 2008; Kucerova \& Stejskal, 2009). Thus, it is possible to better observe the shape and position of the various morphological features of the species. This leads to a better understanding of their functionality and how they relate to the biology and ecology of the species (ARSUSDA, 2000; Wergin et al., 2000).

Unfortunately, many of the SEM techniques previously performed on soft-bodied mites such as Tyrophagus, have often not shown the desired results as collapsing of body and loss of detail of the sensorial setae have occurred (Achor et al., 2001); consequently, the aim of this investigation is to evaluate various SEM procedures and to determine which procedure is the best to preserve the structures, observe and photograph the major morphological characters of $T$. putrescentiae, given the limitations of the equipment and technology available in our country and most other countries in the region.

Low temperature -SEM (LT-SEM) methods have been used in other studies, which have demonstrated excellent results on soft-bodied arthropods including mites (Achor et al., 2001; ARS-USDA, 2007; Erbe, Wergin, Ochoa, Dickens \& Moser, 2001; Ochoa et al., 2001; Wergin et al., 2000; Wergin, Erbe \& Ochoa, 2001; Dowling, Bauchan, Ochoa \& Beard, 2010; Beard et al., 2012). Unfortunately, these methods require very specialized equipment attached to the SEM unit that is not available in Central America, which is why we only evaluated and discussed some techniques used for a standard SEM.

\section{METHODOLOGY}

Mite-contaminated vessels coming from different tissue culture laboratories within the country were taken to the Laboratory of Acarology, University of Costa Rica to corroborate the presence of these organisms on the plants. The material was examined with the aid of an Optima ZM160A stereoscope. Mites found in the vessels were processed immediately according to the treatments. The specimens were later taken to CIEMic (Center of Investigation on Microscopic Structures), University of Costa Rica, for the SEM studies.

The following seven methodologies were used to process the samples of Tyrophagus putrescentiae (Schrank) sensu Klimov \& OConnor (2009):

- Treatment 1: (1) mites were mounted on double-sided carbon tape that was fixed on aluminum stubs; (2) coated with gold/palladium for 10 minutes in an IB-3 (Eiko) sputter coater; (3) viewed in the SEM at an accelerating voltage of $15 \mathrm{kV}$ (Hitachi S-570).

- Treatment 2: (1) mites were placed in Karnovsky fixer (glutaraldehyde 2,5\%, paraformaldehyde 2\%, phosphate buffer $0,1 \mathrm{M}$, distilled water) for 24 hours; (2) washed three times for 15 -minutes each time in a phosphate buffer $(0,1 \mathrm{M})$; (3) placed in an osmium tetraoxide (1\%) post fixation agent for $1 \mathrm{~h}$ at ambient temperature at a $7,2 \mathrm{pH}$; (4) washed three times in distilled water in 15-minute intervals; (5) dehydrated in an increasing series of ethanol concentrations $(30 \%, 50 \%, 70 \%, 80 \%$, $90 \%, 95 \%, 100 \%)$ for 15 minutes in each solution; (6) placed in tertbuthanol, three times for 20 minutes; and (7) dried by sublimation (Freeze dryer VFD-20). (8) Dried samples, they were placed on aluminum stubs with a double-sided carbon tape and coated with gold/palladium in an IB-3 (Eiko) sputter coater; (9) viewed with the SEM at an accelerating voltage of $15 \mathrm{kV}$ (Hitachi S-570).

- Treatment 3: The modified method used by Achor \& Childers (1995) to process samples of thrips. (1) mites previously fixed in $70 \% \mathrm{ETOH}$ were extracted from the alcohol vial; (2) placed into fresh $70 \%$ ethanol for at least 24 hours; (3) dehydrated in increasing concentrations of ethanol solutions $(80 \%, 90 \%, 95 \%, 100 \%)$ in which for each concentration, three changes of ethanol were made every 15 minutes. Finally, three changes in terbuthanol were made every 10 minutes; (4) specimens 
were dried out by sublimation (Freeze Dryer, VFD- 20). (5) Dry samples, were placed on aluminum stubs with a double-sided carbon tape and coated with gold/palladium in an IB-3 (Eiko) sputter coater; (6) viewed with the SEM at an accelerating voltage of $15 \mathrm{kV}$ (Hitachi S-570).

- Treatment 4: (1) live specimens were submerged in $30 \%$ ethanol for 1 hour; (2) three changes were made every 15 -minute in each increasing concentrations of ethanol (30\%, 50\%, 70\%, 80\%, 90\%, 95\%, 100\%); (3) three changes in terbuthanol were made every $10 \mathrm{~min}$ utes; (4) specimens were dried by sublimation (Freeze Dryer, VFD- 20). (5) Dry samples, were placed on aluminum stubs with a double-sided carbon tape and coated with gold/palladium in an IB-3 (Eiko) sputter coater; (6) observed with the SEM at an accelerating voltage of 15kV (Hitachi S-570).

- Treatment 5: (1) live specimens were placed in 30\% ethanol for 24 hours. The same methodology that was used for treatment 4 was followed in this treatment, except the dehydration time was decreased from, 15 to 5 minutes in the concentrations of ethanol, and from 10 to 5 minutes in the terbuthanol (last change of terbuthanol was left overnight at $4^{\circ} \mathrm{C}$ ).

- Treatment 6: the same methodology described for treatment 3 was followed for this treatment, except that the dehydration time was decreased from 15 to 5 minutes in the concentrations of ethanol, and again reduced the time from 10 to 5 minutes in the terbuthanol (last terbuthanol change was left overnight at $4^{\circ} \mathrm{C}$ ).

- Treatment 7: the same methodology described in treatment 3 was followed, with the only difference of changing the drying equipment of sublimation (FD) for the critical point drier (CPD).

\section{RESULTS}

The treatments showed evident differences in regard to preservation of the morphological structures on the specimens (Table 1). Mites in treatment 1 showed severe collapsing of both the body and other morphological characters necessary for their identification i.e. legs completely shrunken, supracoxal setae deformed and collapsed (Fig. 2A), as well as the body (Fig. 1A).

Results of the Tyrophagus preparation using glutaraldehyde as a fixer and carrying an osmium post fixation agent (treatment 2) were also unsatisfactory; even though the legs and setae maintained their original position, the body collapsed, although less than in treatment 1 (Fig. 1B, 3A). Specimens placed in an ethanol fixation solution for 24 hours (treatment 3, treatment 7) showed a considerable improvement over those placed in glutaraldehyde. They maintained most of their body turgidity; however, some collapsing also occurred, especially on the less sclerotized parts of the mites. The legs maintained their normal position (Fig. 1C, 1G), body setae kept their original shape (Fig. $3 \mathrm{~B}, 3 \mathrm{E})$ including the internal vertical (vi) external vertical (ve), internal sacrals (sci), and the external sacrals setae (sce), nevertheless the shape of the supracoxal setae (scx) was better preserved in treatment 3 (Fig. 2B) than in treatment 7 (Fig. 2F).

Treatment 4 showed certain improvements over the use of glutaraldehyde but was less satisfactory than treatments 3 and 7 . Mite legs kept their normal position, the most sclerotized parts of body, such as mouthparts and claws maintained their original shape, whereas the less sclerotized structures collapsed (Fig. 1D), as well as some of the setae of the idiosoma (Fig. 3C). The supracoxal setae showed the same degree of deformation as the other dorsal setae (Fig. 2C).

TABLE 1

Comparative table of the principal Characters vs. Treatments

\begin{tabular}{cccccccc}
\hline Character/Treatment & $\mathbf{1}$ & $\mathbf{2}$ & $\mathbf{3}$ & $\mathbf{4}$ & $\mathbf{5}$ & $\mathbf{6}$ & $\mathbf{7}$ \\
\hline Legs & $\mathrm{U}$ & $\mathrm{S}$ & $\mathrm{G}$ & $\mathrm{G}$ & $\mathrm{G}$ & $\mathrm{G}$ & $\mathrm{G}$ \\
Body integument & $\mathrm{U}$ & $\mathrm{U}$ & $\mathrm{S}$ & $\mathrm{S}$ & $\mathrm{S}$ & $\mathrm{S}$ & $\mathrm{S}$ \\
Dorsal setae & $\mathrm{U}$ & $\mathrm{U}$ & $\mathrm{G}$ & $\mathrm{S}$ & $\mathrm{S}$ & $\mathrm{S}$ & $\mathrm{G}$ \\
vi, ve, sci, sce setae & $\mathrm{U}$ & $\mathrm{U}$ & $\mathrm{G}$ & $\mathrm{S}$ & $\mathrm{G}$ & $\mathrm{G}$ & $\mathrm{G}$ \\
Supracoxal seta & $\mathrm{U}$ & $\mathrm{U}$ & $\mathrm{G}$ & $\mathrm{S}$ & $\mathrm{U}$ & $\mathrm{S}$ & $\mathrm{S}$
\end{tabular}

Good $(G)=$ well preserved, details of character observable.

Satisfactory $(\mathrm{S})=$ character observable but distorted.

Unsatisfactory $(U)=$ character too distorted to be used. 

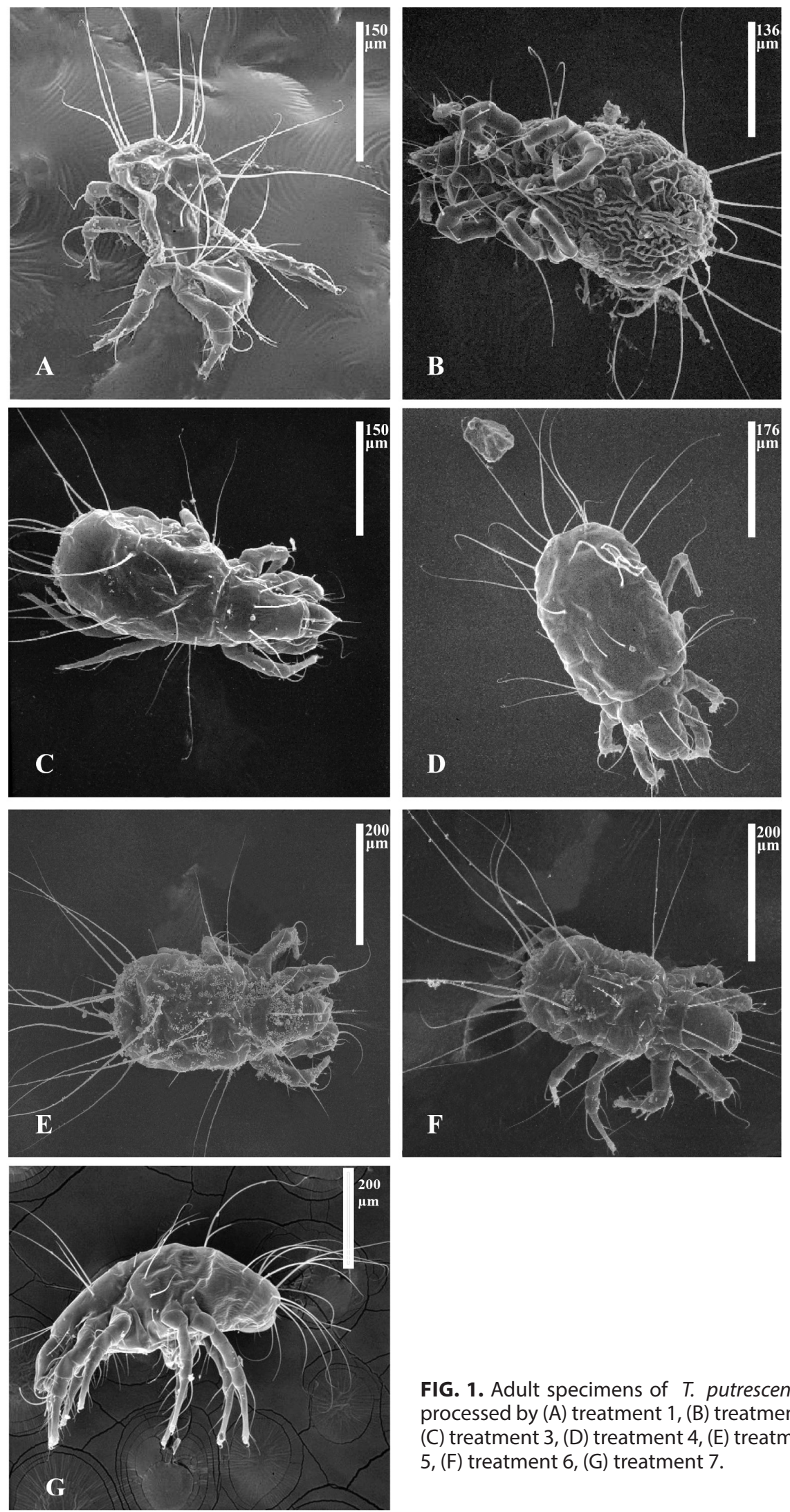

FIG. 1. Adult specimens of $T$. putrescentiae processed by (A) treatment 1 , (B) treatment 2, (C) treatment 3, (D) treatment 4, (E) treatment 5, (F) treatment 6, (G) treatment 7. 

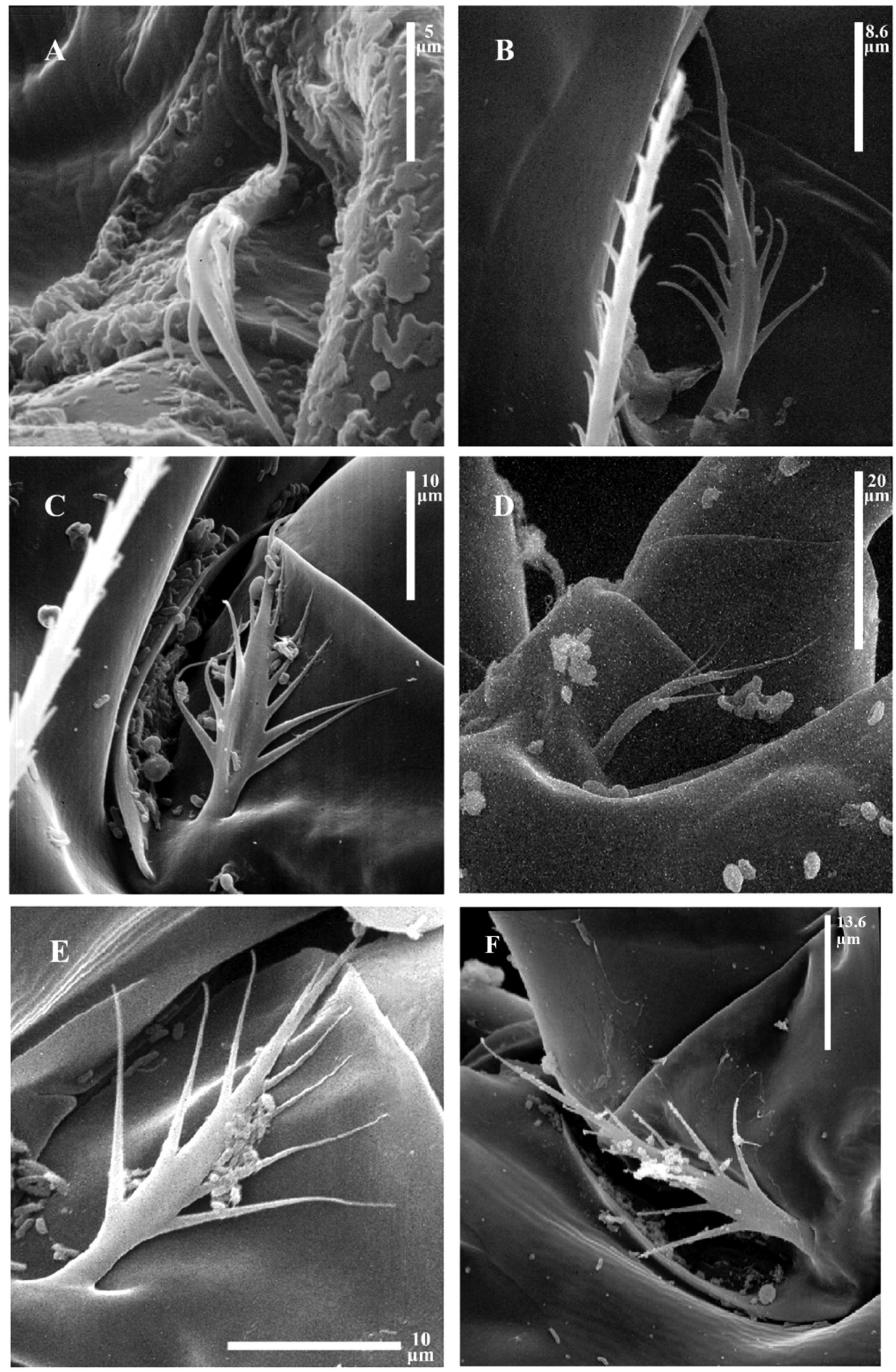

FIG. 2. Supracoxal setae of T. putrescentiae processed by (A) treatment 1 , (B) treatment 3 ,

(C) treatment 4, (D) treatment 5, (E) treatment 6, (F) treatment 7. 

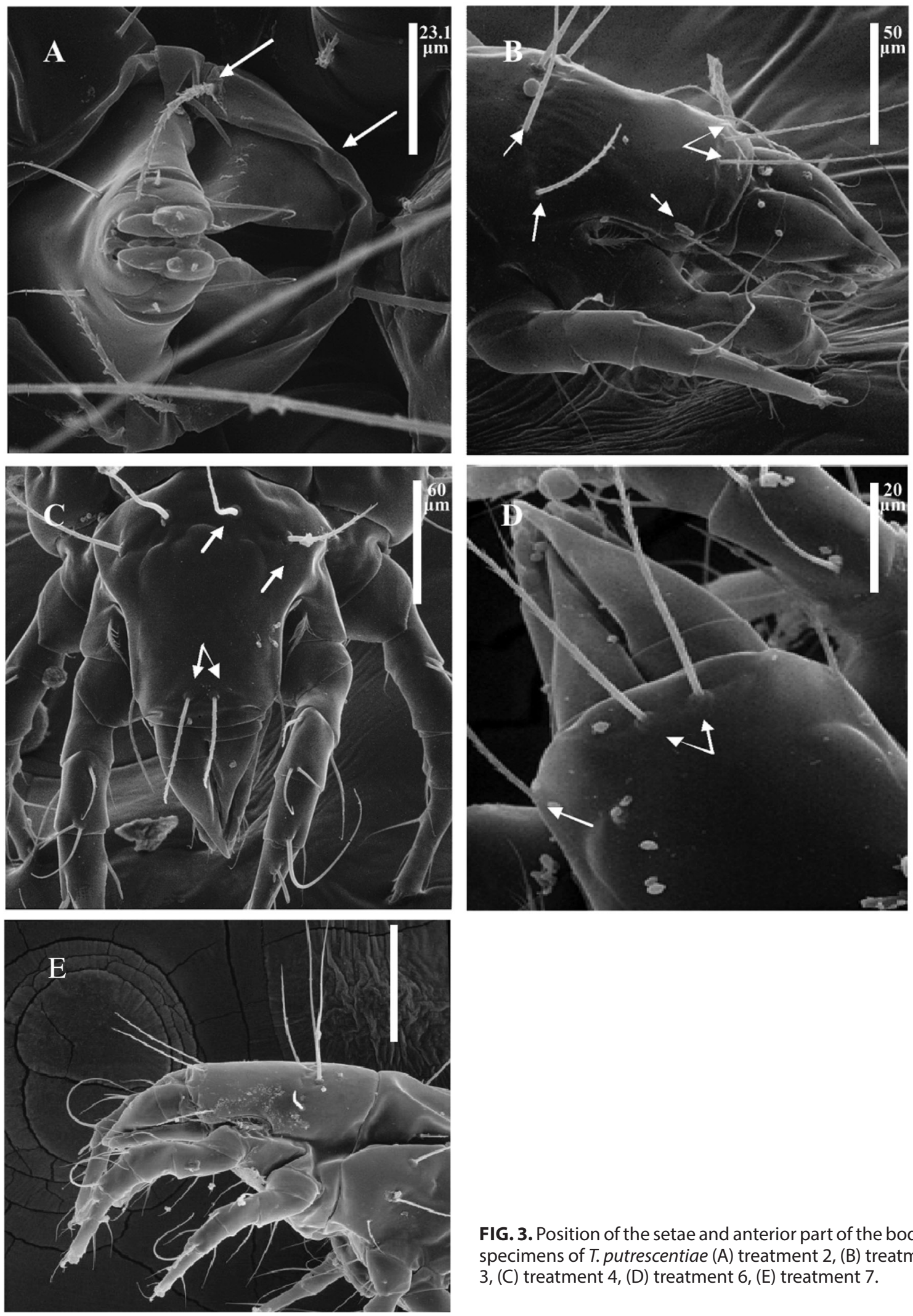

FIG. 3. Position of the setae and anterior part of the body in specimens of T. putrescentiae (A) treatment 2, (B) treatment 3, (C) treatment 4, (D) treatment 6, (E) treatment 7. 
Mites processed with treatments 5 and 6 showed similar results to each other. Collapsing was observed in some parts of the body's cuticle, being more evident on the opisthosoma (Figs. 1E and 1F). The supracoxal setae showed signs of collapse and deformation mostly in treatment 5 where the degree of distortion was greater than in treatment 6 (Figs. 2D and 2E). The rest of setae on gnathosoma and idiosoma maintained their original position in both treatments (Figs. 1E, 3D, 1F).

The most sclerotized parts of the mites, such as the gnathosoma, were well preserved during the different alcohol treatments (Figs. 3B, 3C, 3D, 3E); whereas in the glutaraldehyde treatment some collapsing of the body and other structures occurred (Fig. 3A).

\section{DISCUSSION}

Light microscopy has been traditionally used in working with very small organisms such as mites; however in recent years other tools have been implemented, i.e. electron microscopy to make detailed studies of these and other microscopic organisms. Specimens need to be prepared before they can be observed using the SEM. In most of the cases, this is done using a chemical fixation agent followed by dehydration, critical point dried, mounted on an SEM stub and coated with gold/palladium (OjedaSahagún, 1997).

Soft-bodied organisms such as insect larvae, mites, nematodes and annelids have been difficult to process using conventional techniques for SEM. These techniques involve several steps which cause changes in the structure of the specimens due to the effects of surface tension, osmotic changes and mechanical damage (Erbe et al., 2001).

The body of Tyrophagous mites is very soft, therefore its structures are difficult to preserve in comparison with those having more sclerotized bodies. Specimen preparation by conventional techniques of fixation and drying frequently damage or reorient delicate structures such as setae or segments that are slightly sclerotized (Wergin et al., 2000). Major differences were observed in the ability of each of the treatments to preserve the various body structures of the specimens that were prepared for observation with the SEM. Treatment 1 , in which the specimens received no prior treatment (not fixed or dehydrated) before being placed on SEM stubs and coated with gold/ palladium, was the least adequate method (Figs. 1A, 2A). The body and other structures of mites prepared with this method were completely collapsed.

Common fixation techniques used for the preparation of specimens for observation with SEM such as those using glutaraldehyde and osmium have not shown to be appropriate when working with mites (Achor et al., 2001). The bodies of specimens treated with the glutaraldehyde fixation agent (Figs. 1B, 3A), showed a high degree of collapse and distortion. A possible disadvantage of using this fixative is its slow penetration into the tissues, resulting in poor preservation of the body structures. According to Achor et al. (2001), the infiltration of this fixative into the body could be improved by using a moistener such as the dimethylsulphoxide (DMSO) or by microwave radiation. In addition, this method requires a high degree of specimen manipulation, which might cause some damage during certain steps of the procedure.

Ethanol proved to be a more appropriate fixation technique for mites than the glutaraldehyde (Figs. 1C, 1D, 1E, $1 F, 1 G)$ probably for its high capacity to penetrate the mite cuticle. Although differences in the treatments with alcohol were observed (treatments 3, 4, 5, 6), all showed better results than the methods where the fixation was not used (treatment 1) or by using glutaraldehyde as a fixative (treatment 2).

Differences were observed in specimens in the alcohol treatments based on the amount of time the specimens were immersed in each of the various concentrations and the drying method used. Structures such as the vi, ve, $\mathrm{sci}$, and sce setae showed a lesser degree of deformation when treated with $70 \%$ ethanol and dehydrated every 15 min (Figs. 3B, 3E) using any of the two types of drying, whereas those treated with $30 \%$ ethanol (Figs. 2C, 2D and 3C) showed a higher degree of imperfections of these setae. In case of the scx seta, treatment 3 was the only one that kept the original shape of this seta (Fig. 2B).

Using ethanol is also advantageous since the sample preparation time is reduced because some of the procedure steps, such as fixation and post fixation, can be avoided. In addition, it is not necessary to work with toxic substances such as aldehydes and osmium, and the costs are less for procedures using ethanol than for the other treatments.

Although the alcohol methods were more effective than the other treatments that were evaluated, some parts of the body of mites still showed signs of collapse, especially on the cuticle of the idiosoma, which could be attributed to the drying techniques used. Wergin et al. (2000) considered that the drying techniques commonly used (sublimation and critical point drying) are associated with distortion or collapsing of the biological samples. 


\section{ACKNOWLEDGEMENTS}

We thank Gregory Evans and Charles Murphy from the USDA, Beltsville, Maryland for their review and valuable comments on the manuscript.

\section{REFERENCES}

Achor, D.S. \& Childers, C. (1995). Fixation techniques for observing thrips morphology and injury with electron microscopy. In: B.L. Parker, M. Skinner \& T. Lewis, (Eds.), Thrips biology and management (pp 595-600). New York, NY: Plenum Press.

Achor, D., Ochoa, R., Erbe, E., Aguilar, H., Wergin, W. \& Childers, C. (2001). Relative advantages of low temperature versus ambient temperature scanning electron microscopy in the study of mite morphology. International Journal of Acarology, 27(1), 3-12.

Aguilar, H., Murillo, P. \& Gómez, L.E. (2006). Role of mites in tissue culture laboratories: the case of Siteroptes reniformis in Costa Rica. Abstract Book, 12th International Congress of Acarology 21-26 August, 2006, Amsterdam, The Netherlands.

ARS-USDA. (2000). Mites get frozen, photographed, and identified. Agriculture Research Magazine, 48(10), 4-7.

ARS-USDA. (2007). A Tiny Menace Island-Hops the Caribbean. Agriculture Research Magazine, 55(5), 4-7.

Beard, J.J., Ochoa, R., Bauchan, G., Welbourn, W.C., Pooley, C. \& Dowling, A.P.G. (2012). External mouthpart morphology in the Tenuipalpidae (Tetranychoidea): Raoiella a case study. Experimental and Applied Acarology, 57(3-4), 227-255.

Blake, J. (1988). Mites and thrips as bacterial and fungal vectors between plant tissue cultures. Acta Horticulture, 225, 163- 166.

Boxus, P.H. \& Terzi, J.M. (1987). Big losses due to bacterial contamination can be avoided in mass propagation scheme. Acta Horticulture, 212, 91-93.

Dowling, A.P.G., Bauchan, G.R., Ochoa, R. \& Beard, J. (2010). Scanning Electron Microscopy vouchers and genomic data from an individual specimen: maximizing the utility of delicate and rare specimens. Acarology, 50(4), 479-485.

Duek, L., Kaufman, G., Palevsky, E. \& Berdicevsky, I. (2001). Mites in fungal cultures. Mycoses, 44, 390- 394.

Erbe, E.F., Wergin, W.P., Ochoa, R., Dickens, J.C. \& Moser, B. (2001). Low temperature scanning electron microscopy of soft bodied organisms. Proceedings of the Microscopy Society of America, Microscopy and Microanalysis, 7(2), 1204-1205.

Fan, Q.H. \& Zhang, Z.Q. (2007). Tyrophagus (Acari: Astigmata: Acaridae). Fauna of New Zealand (pp 14- 291). New Zealand, NZ: Manaaki Whenua Press, Lincoln.
Hughes, A.M. (1976). The mites of Stored Food and Houses. Technical Bulletin No.9, Ministry of Agriculture, Fisheries and Food (p 399). London: Her Majesty's Stationary Office.

Keirans, J.E., Clifford, C.M. \& Corwin, D. (1976). Ixodes sigelos, n. sp. (Acarina: Ixodidae), a parasite of rodents in Chile, with a method for preparing ticks for examination by scanning electron microscopy. Acarology, 18(2), 217-25.

Klimov, P.B. \& OConnor, B.M. (2009). Conservation of the name Tyrophagus putrescentiae, a medically and economically important mite species (Acari:Acaridae). International Journal of Acarology, 35(2), 95-114.

Kucerova, Z. \& Stejskal, V. (2009). Morphological diagnosis of the eggs of stored-products mites. Experimental and Applied Acarology, 49(3), 173-183.

Leifert, C., Morris, C. \& Waites, W.M. (1994). Ecology of microbial saprophytes and pathogens in tissue cultured and field grown plants. CRC Critical Reviews in Plant Sciences, 13, 139-89.

Leifert, C. \& Cassells, A.C. (2001). Microbial hazards in plant tissue and cell cultures. In Vitro Cellular and Development Biology, 37, 133-138.

Mariana, A., Santana Raj, A.S., Ho, T.M., Tan, S.N. \& Zuhaizam, H. (2008). Scanning Electron Micrographs of two species of Sturnophagoides (Acari: Astigmata: Pyroglyphidae) mites in Malaysia. Tropical Biomedicine, 25(3), 217-224.

Ochoa, R., Erbe, E.F., Wergin, W.P., Frye, C. \& Lydon, J. (2001). The presence of Aceria anthocoptes (Nalepa) (Acari: Eriophyidae) on Cirsium species in the United States. International Journal of Acarology, 27, 179-187.

Ojeda-Sahagún, J.L. (1997). Métodos de microscopia electrónica de barrido en biología, ( $\mathrm{p}$ 267). Santander: Universidad de Cantabria, D.L.

Postek, M., Howard, K., Johnson, A. \& McMichael, K. (1980). Scanning electron microscopy, ( p 305). USA: Ladd Research Industries, Inc.

Serageldin, I. (1999). Biotechnology and food security in the $21^{\text {st }}$ century. Science, 285, 387-389.

Valdez, M., López, R. \& Jiménez, L. (2004). Estado actual de la Biotecnología en Costa Rica. Revista de Biologia Tropical, $52(3), 733-743$

Wergin, W., Ochoa, R., Erbe, E., Craemer, C. \& Raina, A. (2000). Use of low- temperature field emission scanning electron microscopy to examine mites. Scanning, 22(3), 145-155.

Wergin, W., Erbe, E. \& Ochoa, R. (2001). Versatile and inexpensive specimen holder for high angle azimuth rotation in a low temperature scanning electron microscope. Proceedings of the Microscopy Society of America, Microscopy and Microanalysis, 7(2), 718-719.

Zhang, Z.Q. (2003). Mites of Greenhouses: Identification, Biology and Control, (p 244). Wallingford, UK: CABI Publishing. 